\title{
Synchrony in aquatic microbial community dynamics
}

\author{
Angela D Kent ${ }^{1,2,5}$, Anthony C Yannarell ${ }^{3,6}$, James A Rusak ${ }^{1}$, Eric W Triplett ${ }^{4}$ and \\ Katherine D McMahon ${ }^{2}$ \\ ${ }^{1}$ Center for Limnology, University of Wisconsin-Madison, Madison, WI, USA; ${ }^{2}$ Department of Civil and \\ Environmental Engineering, University of Wisconsin-Madison, Madison, WI, USA; ${ }^{3}$ Institute of Marine \\ Sciences, University of North Carolina at Chapel Hill, Morehead City, NC, USA and ${ }^{4}$ Department of \\ Microbiology and Cell Science, University of Florida, Gainesville, FL, USA
}

\begin{abstract}
Population dynamics are influenced by drivers acting from outside and from within an ecosystem. Extrinsic forces operating over broad spatial scales can impart synchronous behavior to separate populations, while internal, system-specific drivers often lead to idiosyncratic behavior. Here, we demonstrate synchrony in community-level dynamics among phytoplankton and bacteria in six north temperate humic lakes. The influence of regional meteorological factors explained much of the temporal variability in the phytoplankton community, and resulted in synchronous patterns of community change among lakes. Bacterial dynamics, in contrast, were driven by system-specific interactions with phytoplankton. Despite the importance of intrinsic factors for determining bacterial community composition and dynamics, we demonstrated that biological interactions transmitted the signal of the regional extrinsic drivers to the bacterial communities, ultimately resulting in synchronous community phenologies for bacterioplankton communities as well. This demonstrates how linkages between the components of a complex biological system can work to simplify the dynamics of the system and implies that it may be possible to predict the behavior of microbial communities responsible for important biogeochemical services in the landscape.
\end{abstract}

The ISME Journal (2007) 1, 38-47; doi:10.1038/ismej.2007.6

Subject Category: microbial population and community ecology

Keywords: freshwater ecology; community dynamics; synchrony

\section{Introduction}

Microbial communities regulate the flow of nutrients and energy in the Earth's biosphere, but little is known about the forces that govern their structures and functions. Quantifying the influence of these forces is essential to understanding microbially mediated processes. Ecologically, these drivers can be separated into intrinsic (site-specific) and extrinsic (regional) categories and the relative importance of each is a topic of much debate (Grenfell et al., 1998; Hudson and Cattadori, 1999; Rusak et al., 1999; Bjørnstad and Grenfell, 2001; Liebhold et al., 2004; Hessen et al., 2006). Lakes provide an excellent system to explore the influence of intrinsic vs

Correspondence: Dr KD McMahon, Department of Civil and Environmental Engineering, University of Wisconsin-Madison, 1415 Engineering Drive, Madison, WI 53706, USA.

E-mail: tmcmahon@engr.wisc.edu

${ }^{5}$ Current address: Department of Natural Resources and Environmental Sciences, University of Illinois at Urbana-Champaign, Urbana, IL 61801, USA

${ }^{6}$ Current address: Department of Animal Sciences, University of Illinois at Urbana-Champaign, Urbana, IL 61801, USA

Received 19 December 2006; revised and accepted 21 February 2007 extrinsic drivers of microbial communities, since the shoreline boundaries enable us to distinguish forces acting from within and from outside the system. Extrinsic factors operating at a regional scale can be observed as they impose synchrony on the dynamics of various ecosystem parameters (Liebhold et al., 2004). Abiotic variables such as temperature and major ion concentrations, for example, exhibit strong interannual synchrony across lakes in a region (Magnuson et al., 1990; Kratz et al., 1998). Lakespecific intrinsic drivers, such as food-web interactions and stochastic population dynamics, typically dampen such patterns in plankton (Baines et al., 2000; Magnuson et al., 2005).

Previous studies exploring the relative importance of extrinsic and intrinsic factors in population ecology have typically examined synchrony among populations of a single species (Grenfell et al., 1998; Hudson and Cattadori, 1999; Rusak et al., 1999; Liebhold et al., 2004; Hessen et al., 2006). Spatial synchrony (or temporal coherence) refers to correlated temporal variability in the abundance of distinct taxa, usually within regions (Liebhold et al., 2004). In the absence of dispersal, spatial synchrony among populations is often attributed to the 'Moran effect' (extrinsic drivers) or to trophic 
interactions with populations that exhibit spatial synchrony (Grenfell et al., 1998; Hudson and Cattadori, 1999; Liebhold et al., 2004). Concordance is an analogous concept, applied to communities rather than a single taxon, that quantifies the degree to which spatial patterns in community structure are similar among locations or co-occurring taxonomic groups (Paszkowski and Tonn, 2000; Peres-Neto and Jackson, 2001). The notion of 'temporal concordance' implies that compositional shifts among communities occur at the same time and pace, thus providing an invaluable approach to quantifying synchrony from a community perspective.

Annual patterns of succession have been described for the zooplankton and phytoplankton (Sommer, 1989; Anneville et al., 2002), but the predictability and pace of succession varies among lakes owing to local, lake-specific conditions (Rusak et al., 1999; Baines et al., 2000; Bronmark and Hansson, 2005). Predicting population dynamics would appear to be even more challenging for aquatic bacterial populations given their inherent diversity, rapid generation times, and the wide array of factors that can influence their activity and dynamics (Yannarell et al., 2003; Kent et al., 2004; Yannarell and Triplett, 2005). Additionally, defining appropriate taxonomic units for cross-system comparisons of microbial populations is exceedingly difficult. Rather than focusing on the fluctuations of individual populations, we therefore examined seasonal patterns in the composition of planktonic microbial communities and the factors responsible for community dynamics. Synchrony at the community level is virtually unexplored. While some recent studies have examined synchrony in bacterial dynamics across multiple sites, these communities were very similar in composition, and were sampled at a coarser level of temporal resolution (monthly or seasonally) (Stepanauskas et al., 2003; Crump and Hobbie, 2005). Demonstration of concordant community dynamics among lakes over time would indicate that communities also respond in predictable ways to regional extrinsic drivers. Sorting out the relative influence of drivers creating regional patterns in community dynamics and those creating system-specific, idiosyncratic behavior can provide a predictive framework for understanding future environmental change and its effect on microbial communities.

\section{Materials and methods}

\section{Study sites}

Bacterioplankton and phytoplankton communities were examined in six shallow humic lakes located in northern Wisconsin, USA. Physical and chemical limnological characteristics of the lakes are provided in Table 1. These lakes are hydrologically isolated, with no stream or river connections between them. The extensive Sphagnum mat surrounding each lake is responsible for the high concentration of humic substances found in these waters.

\section{Field sampling}

Integrated epilimnion samples were collected twice weekly from May 28 to August 22, 2003, as described previously (Kent et al., 2004). Briefly, epilimnion depth was determined by temperature and dissolved oxygen profiles. Integrated epilimnetic samples were collected at the deepest point in each lake using an integrated water column sampler. Bacteria present in these samples were concentrated onto 0.2- $\mu \mathrm{m}$ filters (Supor-200; Pall Gelman, East Hills, NY, USA). Filters were frozen immediately, and stored at $-80^{\circ} \mathrm{C}$ awaiting DNA extraction using the FastPrep DNA purification kit (MPBiomedicals, Solon, OH, USA). Aliquots were preserved in $2 \%$ glutaraldehyde for determination of phytoplankton identification and abundance, and also for enumeration of bacterioplankton, zooplankton and heterotrophic nanoflagellates (HNF). Samples were also collected for water chemistry analyses.

\section{Planktonic community composition}

Abundance of bacteria, phytoplankton, zooplankton and HNF. To determine bacterial abundance, cells were stained with $4^{\prime}, 6^{\prime}$-diamidino-2-phenylindole (DAPI) and counted on black $0.2 \mu \mathrm{m}$ polycarbonate track etched filter membranes (PCTE) filters using

Table 1 Lake characteristics

\begin{tabular}{|c|c|c|c|c|c|c|c|c|c|}
\hline Lake & Latitude (N) & Longitude (W) & $\begin{array}{c}\text { Surface } \\
\text { area }(\mathrm{Ha})\end{array}$ & $\begin{array}{l}\text { Maximum } \\
\text { depth (m) }\end{array}$ & $\begin{array}{c}D O C \\
(m g / l)\end{array}$ & $p H$ & $\begin{array}{c}\text { Total P } \\
(\mu g / l)\end{array}$ & $\begin{array}{c}\text { Total N } \\
(\mu g / l)\end{array}$ & $\begin{array}{l}\text { Chl a } \\
(\mu g / l)\end{array}$ \\
\hline Crystal Bog & $46^{\circ} 00^{\prime} 26.8^{\prime \prime} \mathrm{N}$ & $89^{\circ} 36^{\prime} 22.5^{\prime \prime} \mathrm{W}$ & 0.56 & 2.5 & 9.5 & $5.1(0.8)$ & $22.3(7)$ & $629.0(261)$ & $22.4(44.2)$ \\
\hline Forestry Bog & $46^{\circ} 02^{\prime} 51.4^{\prime \prime} \mathrm{N}$ & $89^{\circ} 39^{\prime} 04.8^{\prime \prime} \mathrm{W}$ & 0.13 & 2.5 & 10.4 & $5.5(0.4)$ & $27.2(13)$ & 830.5 (369) & $28.1(43.3)$ \\
\hline N. Sparkling Bog & $46^{\circ} 00^{\prime} 16.0^{\prime \prime} \mathrm{N}$ & $89^{\circ} 42^{\prime} 18.6^{\prime \prime} \mathrm{W}$ & 0.47 & 4.5 & 9.5 & $5.2(1.2)$ & $25.4(11)$ & $691.9(206)$ & $27.4(71.3)$ \\
\hline S. Sparkling Bog & $46^{\circ} 00^{\prime} 13.6^{\prime \prime} \mathrm{N}$ & $89^{\circ} 42^{\prime} 19.9^{\prime \prime} \mathrm{W}$ & 0.44 & 8.0 & 11.2 & $5.1(0.9)$ & $21.8(20)$ & $642.0(161)$ & $22.3(34.7)$ \\
\hline Trout Bog & $46^{\circ} 02^{\prime} 27.5^{\prime \prime} \mathrm{N}$ & $89^{\circ} 41^{\prime} 09.6^{\prime \prime} \mathrm{W}$ & 1.01 & 7.9 & 28.0 & $4.8(0.7)$ & $31.6(22)$ & $815.2(237)$ & $31.5(59.5)$ \\
\hline Why Not Bog & $46^{\circ} 00^{\prime} 17.0^{\prime \prime} \mathrm{N}$ & $89^{\circ} 37^{\prime} 30.9^{\prime \prime} \mathrm{W}$ & 1.23 & 6.5 & 6.6 & $5.7(1.1)$ & $18.9(23)$ & $492.9(279)$ & $8.17(15.9)$ \\
\hline
\end{tabular}

Abbreviations: DOC, dissolved organic carbon; total N, total nitrogen; total P, total phosphorus; Chl a, chlorophyll a.

Numbers in parentheses represent the range of observed values (maximum value-minimum value). 
epifluorescence microscopy (Porter and Feig, 1980), as described previously (Kent et al., 2004). HNF were visualized with DAPI and enumerated on black $0.8 \mu \mathrm{m}$ PCTE filters using epifluorescence microscopy (Kent et al., 2004). Detailed information on bacterial and HNF enumeration is also contained in the on-line methods manual for the Microbial Observatory for the North Temperate Lakes Long Term Ecological Research (NTL-LTER) site, which may be accessed at http://microbes.limnology.wisc. edu/methods.htm.

Phytoplankton populations were identified and enumerated microscopically as described previously (Kent et al., 2004). Volumes ranging from 10 to $25 \mathrm{ml}$ of preserved sample were settled in chambers for at least $24 \mathrm{~h}$ before counting. Identification of dominant phytoplankton species was based on Smith (1950), Prescott (1954) and Patterson (1998). Microscopic counts of phytoplankton populations were transformed using biovolume estimates previously generated for species common to these lakes (Graham et al., 2004), before analysis.

Zooplankton populations were identified and enumerated using standard methods (Frost and Montz, 1988).

Bacterioplankton community analysis. Bacterial community composition and diversity were assessed using automated ribosomal intergenic spacer analysis (ARISA) (Fisher and Triplett, 1999), as described previously (Kent et al., 2004; Yannarell and Triplett, 2005). Polymerase chain reactions (PCRs) contained $1 \mu \mathrm{l}$ of lake-extracted DNA and primers typically used for ARISA 1406f, 5'-TGYACACACCGCCCGT-3' (universal, 16S rRNA gene), and 23Sr, 5'-GGGTTBCCCCATTCRG-3' (bacteriaspecific, $23 \mathrm{~S}$ rRNA gene). The $1406 \mathrm{f}$ primer was labeled at the 5' end with the phosphoramidite dye 6-FAM. PCR was carried out in an Eppendorf MasterCycler Gradient (Eppendorf AG, Hamburg, Germany) with an initial denaturation at $94^{\circ} \mathrm{C}$ for $2 \mathrm{~min}$, followed by 30 cycles of $94^{\circ} \mathrm{C}$ for $35 \mathrm{~s}, 55^{\circ} \mathrm{C}$ for $45 \mathrm{~s}$, and $72^{\circ} \mathrm{C}$ for $2 \mathrm{~min}$, with a final extension carried out at $72^{\circ} \mathrm{C}$ for $2 \mathrm{~min}$. Denaturing capillary electrophoresis was carried out for each PCR using an ABI PRISM 3700 DNA Analyzer (Applied Biosystems, Foster City, CA, USA) as described previously (Kent et al., 2004; Yannarell and Triplett, 2004). Size-calling was carried out using GeneScan 3.1.2 (Applied Biosystems). Capillary electrophoresis results in minor run-to-run variations in observed vs actual fragment length that were resolved using the allele-calling features in Genotyper 2.5 (Applied Biosystems) before analysis. To include the maximum number of peaks while excluding background fluorescence, a threshold of 100 fluorescence units was used. The signal strength (i.e. peak area) of each peak was normalized to account for run-to-run variations in signal detection by dividing the area of individual peaks by the total fluorescence (area) detected in each profile, expressing each peak as a proportion of the observed community (Rees et al., 2004; Yannarell and Triplett, 2005).

\section{Environmental data}

Chemical analyses were conducted as outlined by the North Temperate Lakes Long-Term Ecological Research (NTL-LTER) site (http://lterquery.limnology. wisc.edu) (Stanley, 2003). The environmental dataset includes water temperature and dissolved oxygen profiles, total phosphorus (total P), total nitrogen (total $\mathrm{N}$ ), and dissolved organic carbon (DOC) concentrations, $\mathrm{pH}$ and chlorophyll a (Chl a) concentrations. Total P, total N, DOC and Chl a measures were $\log _{10}$-transformed before analysis. The transformed data were confirmed to exhibit normal distributions.

\section{Meteorological data}

A meteorological dataset was included to examine external factors acting at a regional scale. This data set included a 3-day moving average of mean daily air temperature, photosynthetically active radiation (PAR), and precipitation measured at the municipal airport in nearby Woodruff, WI. Meteorological data for these study sites are available through the NTLLTER's on-line data sets (http://lterquery.limnology. wisc.edu) (Rusak and Kratz, 2003).

\section{Data analysis}

Correspondence analysis was carried out using bacterial community composition data generated by ARISA, and separately for phytoplankton community composition based on biovolume estimates for algal populations present on each date. All correspondence analyses were carried out using Canoco 4.5.1 (Biometris-Plant Research International, Wageningen, The Netherlands) (ter Braak and Smilauer, 2002).

The Bray-Curtis similarity coefficient (Legendre and Legendre, 1998) was calculated using the ARISA data generated from each sample to assess the degree of similarity between bacterial communities obtained from different samples:

$$
S_{j k}=1-\sum \frac{\left|y_{i j}-y_{i k}\right|}{\left(y_{i j}+y_{i k}\right)}
$$

where $y_{i j}$ is the normalized peak area of the ith population in the $j$ th sample and $y_{i k}$ is the normalized peak area of the ith population in the $k$ th sample. A similarity matrix was generated for all possible pairs of samples. This similarity matrix was used to generate analysis of similarity (ANOSIM) statistics (Clarke and Green, 1988) to test the hypothesis that bacterial communities from the same lake were more similar in composition to each other than to communities in different lakes. ANOSIM generates a test statistic, $R$. The magnitude 
of $R$ indicates the degree of separation between groups of samples, with a score of 1 indicating complete separation and 0 indicating no separation. Calculation of similarity coefficients and ANOSIM analyses were carried out using PRIMER 5 for Windows v. 5.2.7 (PRIMER-E Ltd, Plymouth, UK).

Procrustean matrix superimposition was used to assess the degree of association, or concordance, between the temporal patterns in phytoplankton and bacterial community composition within each lake, and for bacterial and phytoplankton communities separately among lakes using the first three axes from correspondence analyses (Jackson, 1995; Legendre and Legendre, 1998; Peres-Neto and Jackson, 2001). The sum of squared residuals between scaled and rotated configurations of each ordination solution is used as a metric of association $\left(\mathrm{m}^{2}\right)$ (Peres-Neto and Jackson, 2001). The $\mathrm{m}^{2}$ metric varies between 0 and 1 , and smaller values of $m^{2}$ indicate stronger concordance between data sets. Significance was assessed by permutation tests (999 permutations) using the PROTEST package (Jackson, 1995).

Variance partitioning using partial canonical correspondence analysis distinguished the relative importance of different sets of variables for explaining the temporal patterns of bacteria or phytoplankton community composition in each lake (ter Braak and Smilauer, 2002). Three sets of potential explanatory variables were used: environmental $(\mathrm{pH}$, total $\mathrm{P}$, total N, DOC and water temperature), meteorological (described above), and biotic variables (chl a, phytoplankton populations and HNF were included as biotic explanatory variables for the bacterioplankton data set, while cladoceran zooplankton populations were included as biotic explanatory variables for the phytoplankton data set). The unique contribution of individual groups of variables was determined by removing the influence of two of the groups of variables (covariables) and using the remaining group as the explanatory set of variables. These partial ordinations were then compared to the total variance explained when all categories are included in the analysis.

\section{Results}

Different bacterial communities were observed in each lake (ANOSIM $R=0.604, P<0.001$ ), and much of this difference was related to water chemistry parameters such as total nitrogen, total phosphorus, DOC and pH (Figure 1). Within each lake, bacterial and phytoplankton community composition were highly variable over the study period, particularly in the month of June (Figure 2). Bray-Curtis similarity coefficients indicated that bacterial communities observed on the last day of sampling were, on average, only $30 \%$ similar to those observed on the first day; phytoplankton communities observed at the end of the sampling period were, on average,

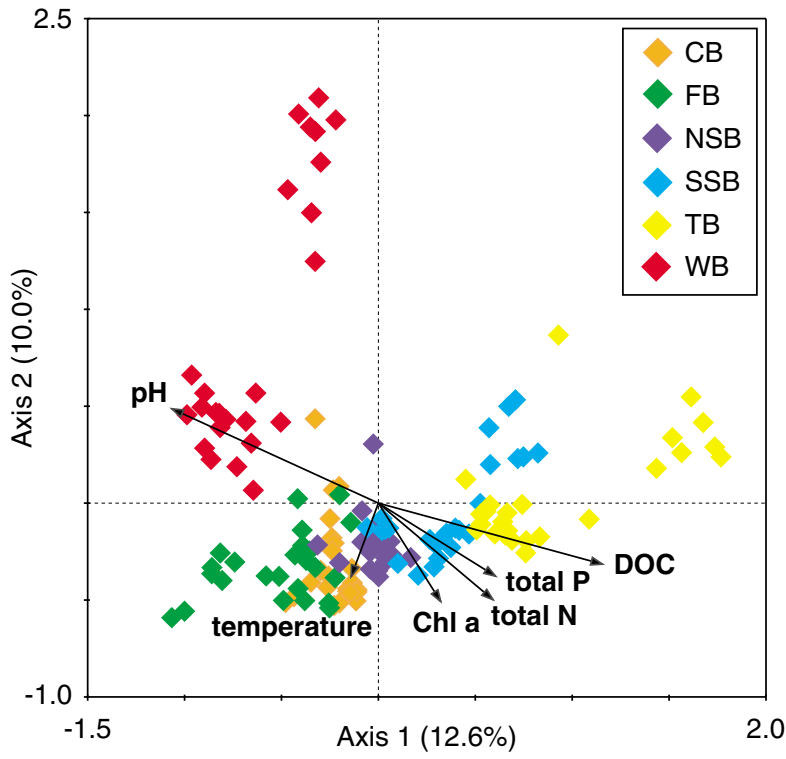

Figure 1 Correspondence analysis biplot of bacterial community composition. Bacterial communities were compared using ARISA relative fluorescence in a suite of six humic lakes in northern Wisconsin (CB, Crystal Bog; FB, Forestry Bog; NSB, N. Sparkling Bog; SSB, S. Sparkling Bog; TB, Trout Bog; WB, Why Not Bog). Points represent bacterial community samples collected twice weekly between May 28 and August 22 2003, from each lake. Arrows for the supplemental chemical and physical variables included in this analysis show the direction of increase for each variable, and the length of each arrow indicates the degree of correlation with the ordination axes. Total N, total nitrogen; total $\mathrm{P}$, total phosphorus; Chl a, chlorophyll a; surface temp, surface water temperature; DOC, dissolved organic carbon. Percentage of community variance explained by each axis is indicated in parentheses. The first two CA axes explain 55.8\% of the relationship between the bacterial community and environment (the 'species-environment relationship' from Canoco). This plot indicates that TB and WB differ the most in bacterial community composition, and also in water chemistry parameters.

only $27 \%$ similar to those observed in May. However, phytoplankton and bacterial community dynamics within each lake were strongly concordant (Table 2), indicating that synchronous shifts occurred in both communities. This temporal concordance was particularly strong in Crystal Bog (CB), Forestry Bog and South Sparkling Bog. We also detected significant community concordance among lakes (Table 3), indicating that synchronous changes occurred in the planktonic microbial assemblages across the region despite the hydrologic isolation of these lakes and the lake-specific community composition.

Because synchrony in population dynamics is often attributed to the influence of extrinsic forcing (Grenfell et al., 1998; Liebhold et al., 2004), we used canonical multivariate analyses to investigate whether similar drivers are responsible for community-level synchrony. We explored the dependence of bacterial and phytoplankton community dynamics on meteorological factors and physical/chemical factors that have shown synchrony (or temporal coherence) in previous studies (Magnuson et al., 
bacteria
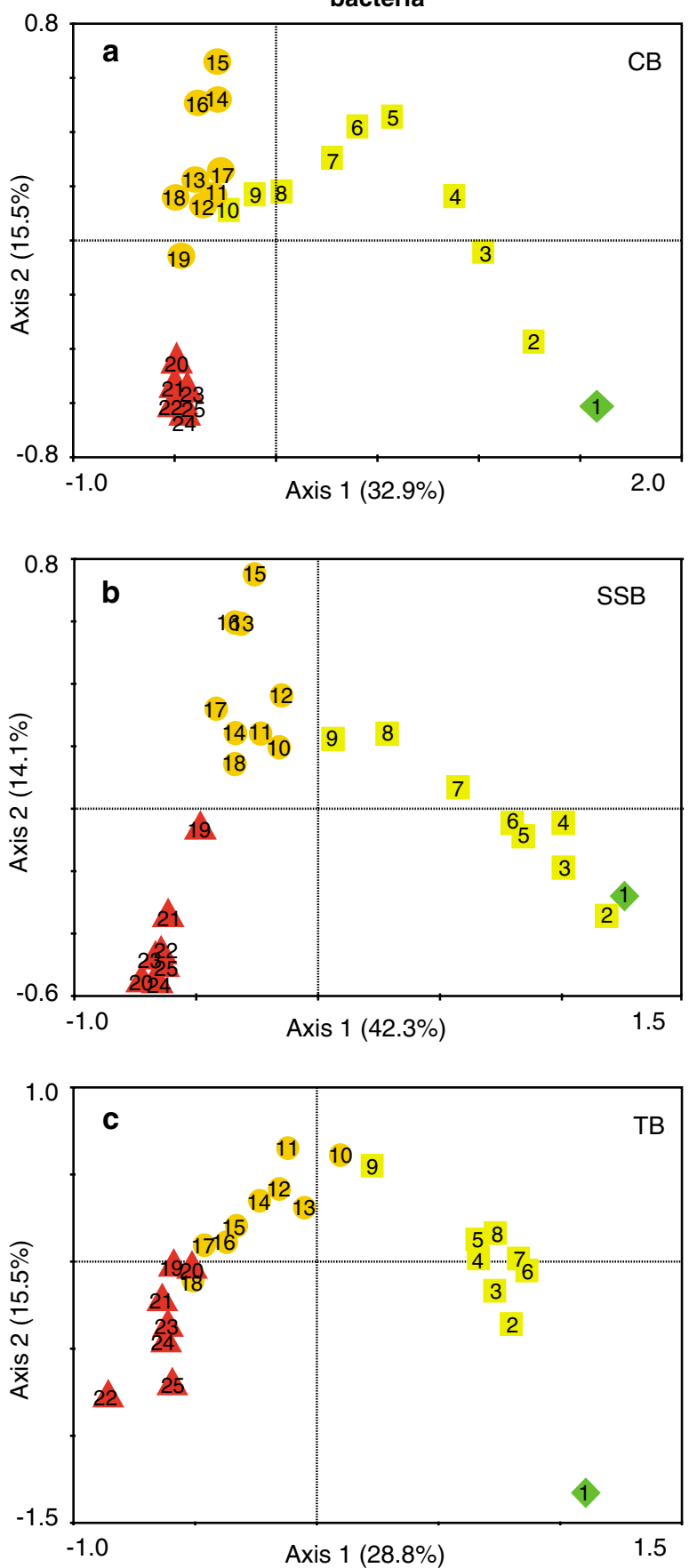
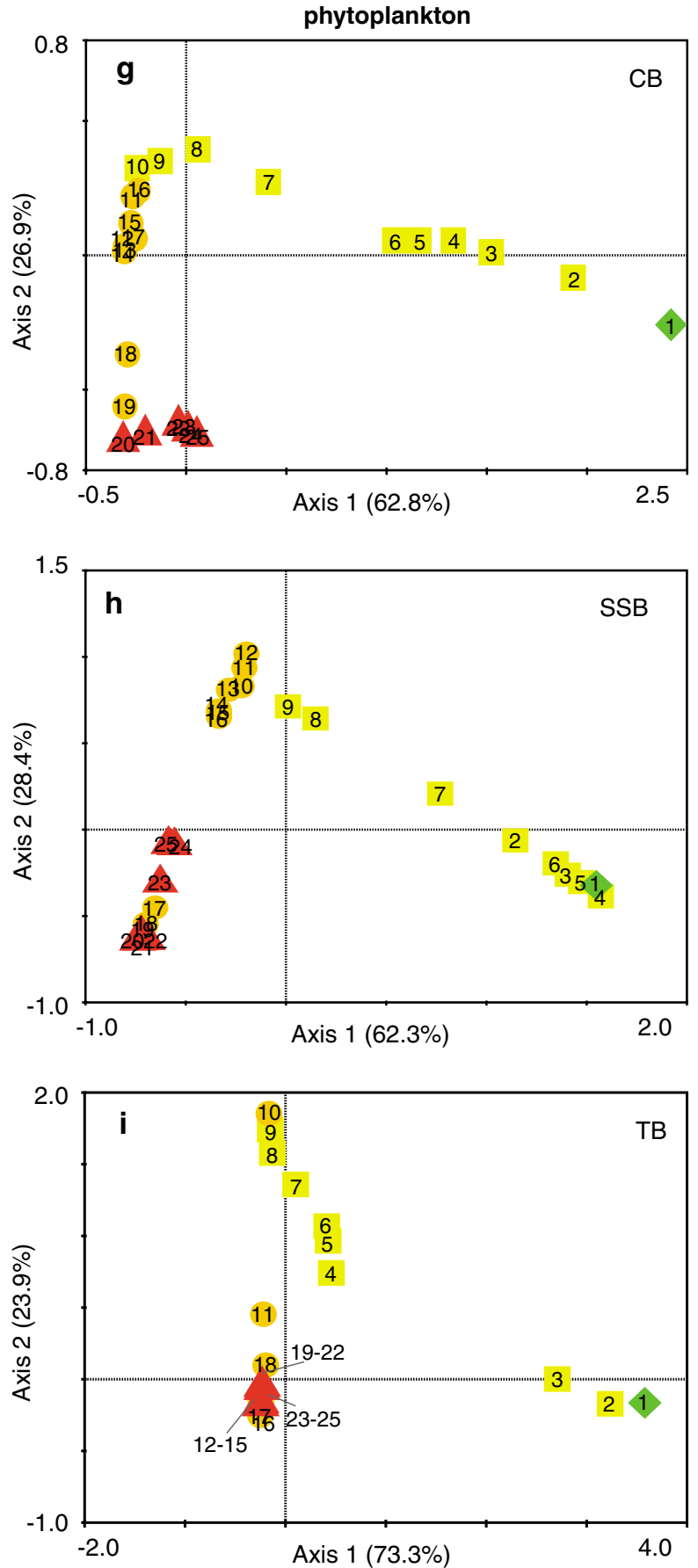

Figure 2 Correspondence analysis of planktonic microbial communities. Bacterial community composition (a-f) and phytoplankton community composition (g-l) in samples collected twice weekly between May 28 and August 22, 2003, from each lake. Points representing sample dates are numbered consecutively, and the color indicates the month in which the sample was collected (green, May; yellow, June; orange, July; red, August). Percentage of community variance explained by each axis is indicated in parentheses. See Figure 1 legend for lake acronym definitions.

2005). In addition, we examined the impacts of biological interactions within each lake by assessing the influence of zooplankton communities on phytoplankton and the influence of phytoplankton and nanoflagellate grazers on bacteria.

Extrinsic meteorological and local environmental variables explained $46 \%$ of within-lake phytoplankton variability (Figures 3a and 4), while biotic interactions accounted for very little. On average, $37 \%$ of variance in lake chemical and physical parameters could be attributed to regional meteorological factors, with water temperature being most strongly correlated ( $81 \%$ of variance in water temperature among lakes was explained by the meteorological factors). Thus, 

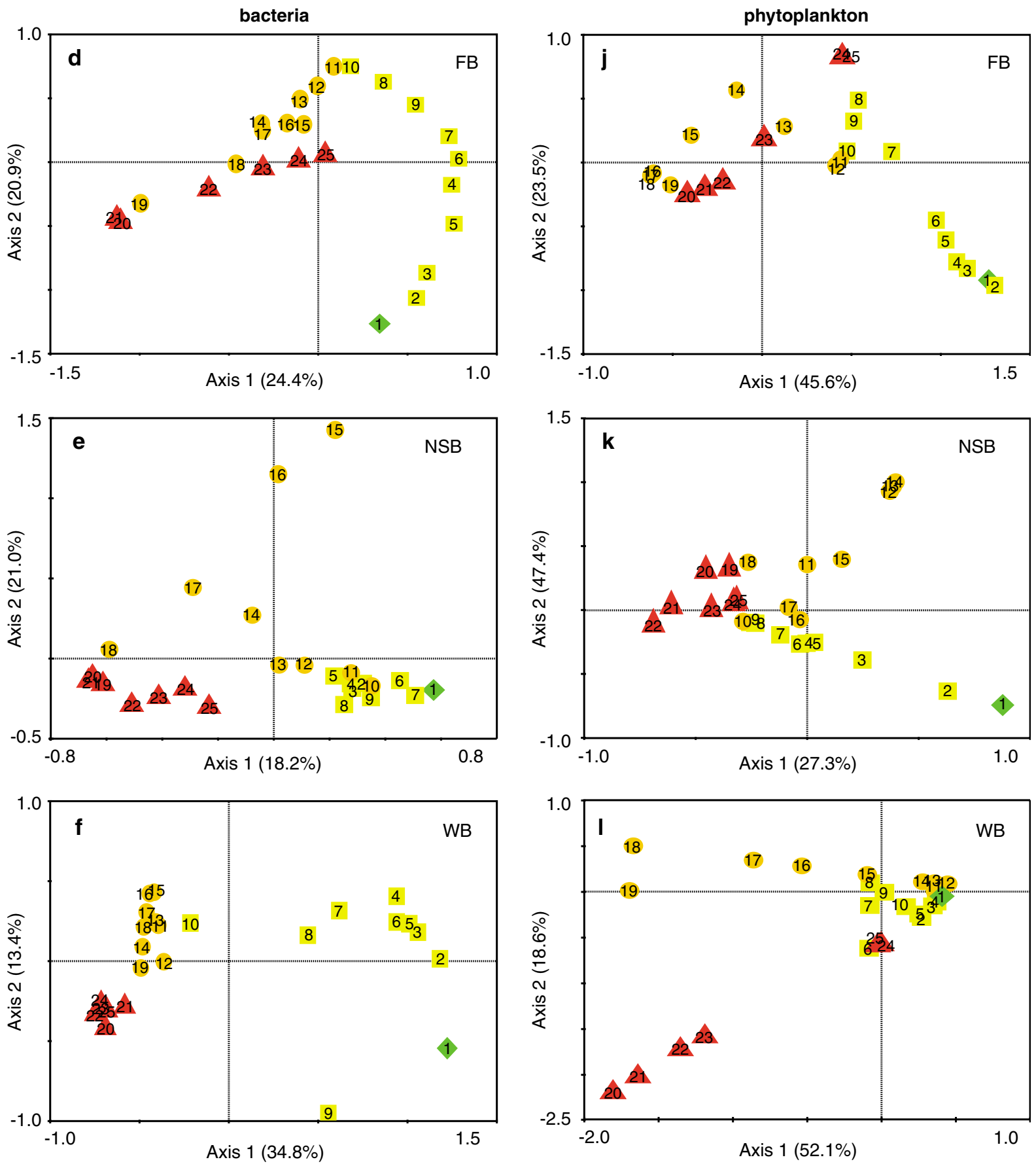

Figure 2 Continued.

patterns in phytoplankton communities were largely explained by extrinsic and abiotic variables acting across the region (e.g. trends in water temperature). In contrast, these parameters explained very little of the within-lake patterns for bacteria (Figures $3 \mathrm{~b}$ and 5). While the combination of meteorology, biotic interactions and local environmental variables accounted for $94 \%$ of the bacterial variation, much of the explanatory power $(40 \%)$ was attributable to biotic interactions with phytoplankton acting independently of other factors. A further $25 \%$ of bacterial variation was attributable to covariation of phytoplankton with local environmental and meteorological factors.

\section{Discussion}

Significance of synchrony and temporal concordance Cross-system differences in community composition and strong biological interactions within each system would be expected to impart distinct dynamics to communities in different lakes. Sur- 
Table 2 Temporal concordance between bacterioplankton and phytoplankton communities in each lake

\begin{tabular}{ll}
\hline Lake & $m^{2}$ \\
\hline Crystal Bog & 0.25 \\
Forestry Bog & 0.37 \\
N. Sparkling Bog & 0.66 \\
S. Sparkling Bog & 0.28 \\
Trout Bog & 0.51 \\
Why Not Bog & 0.68
\end{tabular}

Concordance was determined by Procrustean matrix superimposition of correspondence analysis results from bacterial and phytoplankton communities in each lake (Paszkowski and Tonn, 2000; Peres-Neto and Jackson, 2001). A smaller value of $\mathrm{m}^{2}$ implies a stronger concordance. Mean $\mathrm{m}^{2}=0.46, P<0.001$ for all within-lake comparisons.

Table 3 Community concordance among lakes

\begin{tabular}{lllllll}
\hline & CB & FB & NSB & SSB & TB & WB \\
\hline Crystal Bog & 0 & 0.35 & 0.40 & 0.26 & 0.33 & 0.76 \\
Forestry Bog & 0.32 & 0 & 0.53 & 0.26 & 0.56 & 0.65 \\
N. Sparkling Bog & 0.29 & 0.39 & 0 & 0.54 & 0.56 & 0.66 \\
S. Sparkling Bog & 0.14 & 0.30 & 0.38 & 0 & 0.60 & 0.57 \\
Trout Bog & 0.24 & 0.38 & 0.46 & 0.27 & 0 & $0.86^{*}$ \\
Why Not Bog & 0.46 & 0.58 & 0.52 & 0.31 & 0.51 & 0
\end{tabular}

Concordance was determined by Procrustean matrix superimposition of correspondence analysis results from bacterial or phytoplankton communities among lakes (Paszkowski and Tonn, 2000; Peres-Neto and Jackson, 2001). Phytoplankton comparisons are displayed in the upper right portion of the table (mean $\mathrm{m}^{2}=0.53$ ), and bacterial comparisons are displayed in the lower left portion of the table (mean $m^{2}=0.37$ ). A smaller value of $\mathrm{m}^{2}$ implies a stronger concordance. $P<0.001$ for all between-lake comparisons except some comparisons involving WB (* not significant, $P>0.05$ ).

prisingly, the planktonic communities in this study displayed concordant dynamics among lakes, despite lake-specific differences in microbial community composition (Figures 1 and 2, Table 3). This concordance, or synchrony, implies a predictability to community dynamics and can help delineate the relative influence of deterministic vs stochastic events on ecological systems (Sugihara, 1995; Grenfell et al., 1998).

Synchronous change is ultimately the footprint of environmental factors acting at a regional scale to influence chemical, physical or biological lake variables (Magnuson et al., 2005). The signal may be obscured as it is filtered through intrinsic, or sitespecific, regulators of lake parameters. Synchrony depends, in part, on the directness of a variable's connection to the regional-scale drivers, and on the number of intrinsic, lake-specific factors with the potential to influence the dynamics of a variable (Magnuson et al., 2005). We limited the gradient of local environmental variables by looking only at small humic lakes. Across lake types, with wider ranges of nutrients, depth and size, we might expect that local factors play a stronger role. This is true for
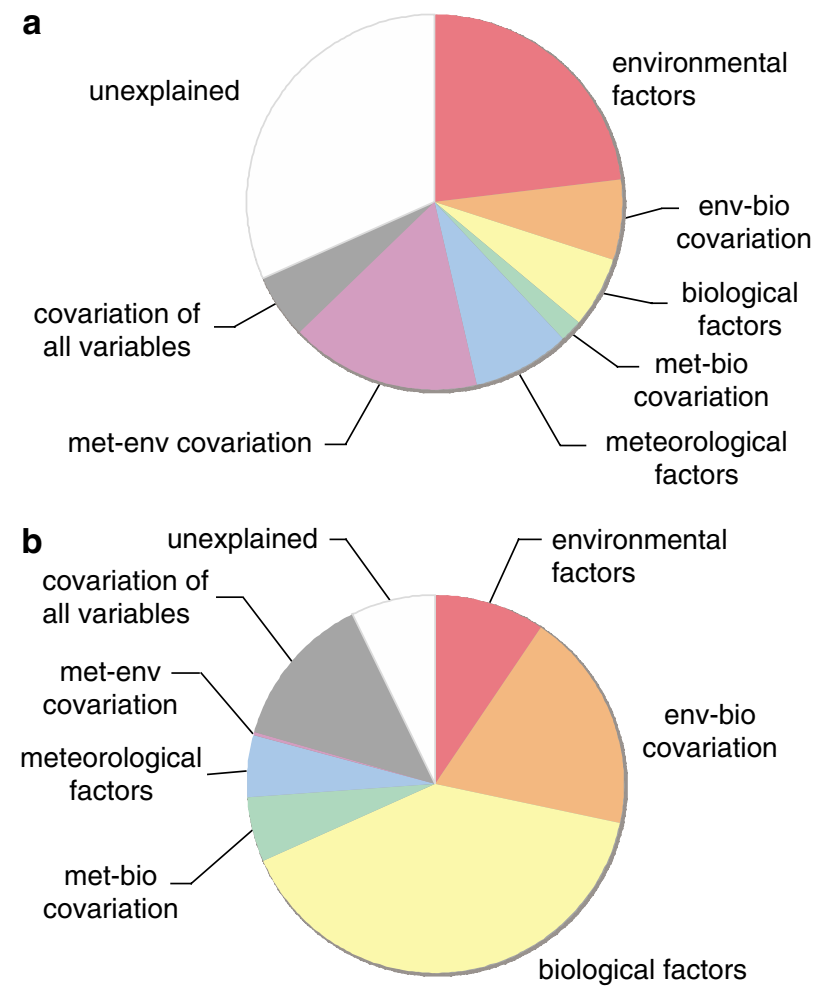

Figure 3 Partitioning microbial community variance among intrinsic and extrinsic variables. (a) Phytoplankton or (b) bacterioplankton community temporal variance was partitioned among meteorological (met), environmental (env) and biological (bio) sets of variables for each lake and variance partitioning results were averaged among lakes. The sets of potential explanatory variables were defined as follows: environmental $\mathrm{pH}$, total P, total N, DOC and water temperature; meteorological 3-day moving average of mean daily air temperature, PAR and precipitation; biological - Chl a, phytoplankton populations and HNF were used as biotic explanatory variables for the bacterioplankton data set, cladoceran zooplankton populations were used as biotic explanatory variables for the phytoplankton data set.

phytoplankton communities in temperate lakes across a trophic gradient (Anneville et al., 2002). Indeed, humic lakes exhibit the strongest levels of synchrony in abiotic variables, compared to other lake types (Jarvinen et al., 2002). In addition, the simple food webs found in these lakes (no planktivorous fishes) may also reduce the number of intrinsic factors with the potential to influence phytoplankton and bacterioplankton community composition.

Spatial synchrony is generally attributed to the influence of regional meteorological factors on the dynamics of discrete populations (Hudson and Cattadori, 1999; Liebhold et al., 2004). Here, we demonstrated that synchronous patterns of succession were robust enough to be detected both in different taxa (phytoplankton and bacterioplankton) and in communities of differing composition, arguing that strong regional environmental drivers are ultimately responsible for determining the 


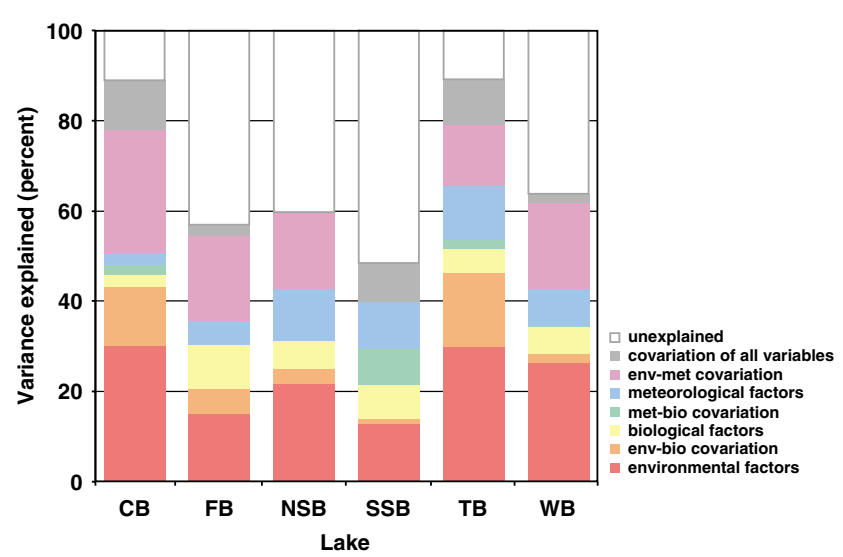

Figure 4 Results of phytoplankton variance partitioning for each lake. Variance in phytoplankton community composition over time (assessed by biovolume) was partitioned among meteorological (met), environmental (env) and biological (bio) sets of variables using partial canonical correspondence analyses. The sets of potential explanatory variables were defined as follows: environmental - pH, total $\mathrm{P}$, total $\mathrm{N}$, DOC and water temperature; meteorological, 3-day moving average of mean daily air temperature, PAR and precipitation; biological - chl a, phytoplankton populations and HNF were used as biotic explanatory variables for the bacterioplankton data set, cladoceran zooplankton populations were used as biotic explanatory variables for the phytoplankton data set. Abiotic factors included in the meteorological and environmental data sets explain more of the variance in phytoplankton community composition in each lake than do biotic variables. See Figure 1 legend for lake acronym definitions.

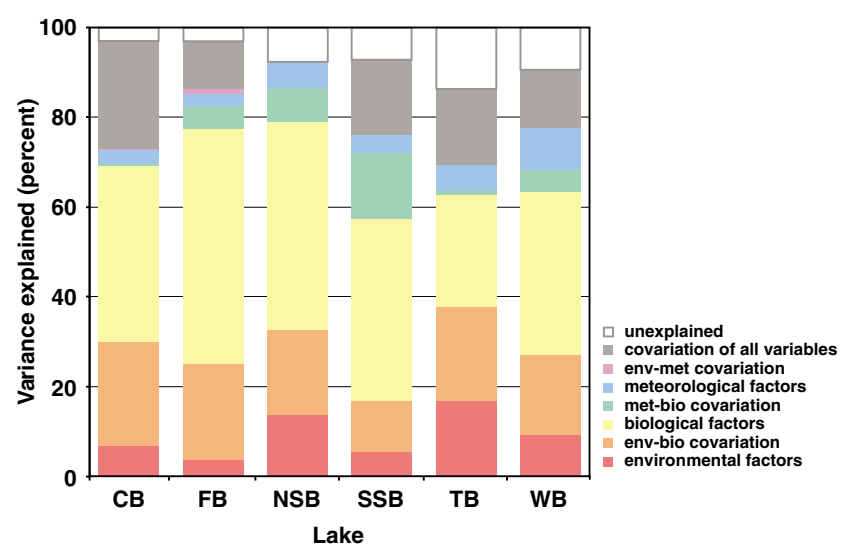

Figure 5 Results of bacterioplankton variance partitioning for each lake. Variance in bacterial community composition over time (assessed by ARISA relative fluorescence) was partitioned among meteorological (met), environmental (env) and biological (bio) sets of variables using partial canonical correspondence analyses. The sets of potential explanatory variables were defined as follows: environmental - $\mathrm{pH}$, total $\mathrm{P}$, total $\mathrm{N}$, DOC and water temperature; meteorological - 3-day moving average of mean daily air temperature, PAR and precipitation; biological - chl a, phytoplankton populations and HNF were used as biotic explanatory variables for the bacterioplankton data set, cladoceran zooplankton populations were used as biotic explanatory variables for the phytoplankton data set. The suite of biotic variables explains much of the variance in bacterial community composition over time in each lake. See Figure 1 legend for lake acronym definitions. structure of planktonic populations in humic lakes. The variance partitioning results indicated strong correlations between regional factors and phytoplankton community dynamics (Figures 3 and 4), suggesting regional control of phytoplankton in these systems. Although we also observed synchrony in community succession for the bacteria in these lakes, this temporal concordance did not appear to be due to the direct influence of extrinsic drivers (Figures 3 and 5). Intrinsic factors, notably the interactions with other planktonic populations, are likely to be the proximate drivers of bacterial community dynamics within each lake. Because the phytoplankton communities are themselves exhibiting temporal concordance (synchrony), we propose that these biotic interactions are transmitting the regional signal to the bacteria (i.e. covariation of biological variables with meteorology and environment, Figures 3 and 5), producing the observed temporal concordance among lakes (Table 3).

Resource-mediated (bottom-up) control may be the mechanism by which the regional environmental signal is passed along from the phytoplankton to the bacterial communities. While these humic lakes are consistently high in DOC, a large fraction of this is presumed to be comprised of recalcitrant humic compounds (Malcolm, 1990; Wetzel et al., 1995). Succession in the phytoplankton community (driven by regional environmental factors) likely affects the concentration and biochemical composition of autochthonous organic matter available to bacteria (van Hannen et al., 1999; Arrieta and Herndl, 2002; Pinhassi et al., 2004). Mesocosm and field studies have demonstrated that dissolved organic matter of differing quality will enrich different bacterial populations, thus influencing the composition of bacterial communities (van Hannen et al., 1999; Crump et al., 2003). We have previously noted within-lake concordance between bacterial and phytoplankton communities (in CB) and proposed that phytoplankton community composition provides a useful proxy for evaluating diversity and abundance of labile organic carbon resources available to aquatic bacteria (Kent et al., 2006). The within-lake concordance between bacterial and phytoplankton communities observed in these systems (Table 2) may therefore be due to the evolving resource base of autochthonous carbon (van Hannen et al., 1999; Kisand and Tammert, 2000; Arrieta and Herndl, 2002). The among-lake concordance observed for bacterial communities (Table 3), as noted above, is likely due to the effects of regional drivers acting to synchronize the dynamics of the phytoplankton communities. Although we cannot rule out the possibility that the bacteria are also synchronizing phytoplankton community dynamics through mechanisms such as competition, allelopathy and nutrient recycling, the evidence presented here taken together with the previous studies described above supports the hypothesis that synchronization of bacterial community dynamics is driven most 
directly by phytoplankton-bacteria interactions. Notably, the weakest concordance values observed within or among lakes involved comparisons with Why Not Bog (WB) (Tables 2 and 3), which had significantly lower phytoplankton biovolume than the other lakes in this study (Table 1). These results suggest that phytoplankton communities are an important link between aquatic bacterial communities and regional environmental drivers.

\section{Conclusion}

The concordant dynamics observed in this study demonstrate how general patterns may emerge in microbial systems despite the immense diversity and complexity of their communities. Conceptual and mechanistic models are needed to predict the behavior of microbial communities, given their integral role in ecosystem function. The results of this study identify important environmental drivers that should be included in such models. Although indirectly linked to regional climate via phytoplankton dynamics, the existence of concordance suggests that bacterial community composition and dynamics in humic lake ecosystems (and by extension, the ecological processes mediated by these microbial communities) are strongly influenced by extrinsic drivers. Recognition of such general organizing forces suggests that dynamics of microbial communities are less idiosyncratic than expected and that the regular patterns imposed by these environmental drivers may have predictive power in other ecosystems. This has important implications for macroscale research challenges ranging from the cycling of nutrients and matter at landscape levels to regional ecosystem management and the forecasting of ecosystem responses to global change.

\section{Acknowledgements}

We gratefully acknowledge the technical assistance of A Ecker, J Epstein, J Morrison, J Thoyre, and the logistical support of the University of Wisconsin-Madison Trout Lake Research Station. We thank SE Jones, T Kratz, S Carpenter, and B Benson, C Horner-Devine, R Whitaker and $J$ Handelsman for thoughtful comments on the manuscript. This research was supported in part by National Science Foundation Grants MCB-9977903, MCB-0401987 and DEB-0217533 and by the University of Wisconsin-Madison Graduate School.

\section{References}

Anneville O, Souissi S, Ibanez F, Ginot V, Druart JC, Angeli N. (2002). Temporal mapping of phytoplankton assemblages in Lake Geneva: Annual and interannual changes in their patterns of succession. Limnol Oceanogr 47: 1355-1366.
Arrieta J, Herndl G. (2002). Changes in bacterial-glucosidase diversity during a coastal phytoplankton bloom. Limnol Oceanogr 47: 594-599.

Baines SB, Webster KE, Kratz TK, Carpenter SR, Magnuson JJ. (2000). Synchronous behavior of temperature, calcium, and chlorophyll in lakes of northern Wisconsin. Ecology 81: 815-825.

Bjørnstad ON, Grenfell BT. (2001). Noisy clockwork: time series analysis of population fluctuations in animals. Science 293: 638-643.

Bronmark C, Hansson L-A. (2005). The Biology of Lakes and Ponds. Oxford University Press: Oxford.

Clarke KR, Green RH. (1988). Statistical design and analysis for a 'biological effects' study. Mar Ecol Prog Ser 46: 213-226.

Crump BC, Hobbie JE. (2005). Synchrony and seasonality in bacterioplankton communities of two temperate rivers. Limnol Oceanogr 50: 1718-1729.

Crump BC, Kling GW, Bahr M, Hobbie JE. (2003). Bacterioplankton community shifts in an arctic lake correlate with seasonal changes in organic matter source. Appl Environ Microbiol 69: 2253-2268.

Fisher MM, Triplett EW. (1999). Automated approach for ribosomal intergenic spacer analysis of microbial diversity and its application to freshwater bacterial communities. Appl Environ Microbiol 65: 4630-4636.

Frost TM, Montz PK. (1988). Early zooplankton response to experimental acidification in Little Rock Lake, Wisconsin, USA. Verhandlungen Internationale Vereinigung fur Theoretische und Angewandte Limnologie 23: 2279-2285.

Graham JM, Kent AD, Lauster GH, Yannarell AC, Graham LE, Kratz TK et al. (2004). Seasonal dynamics of phytoplankton and protoplankton communities in a northern temperate humic lake: diversity in a dinoflagellate dominated system. Microb Ecol 48: 528-540.

Grenfell BT, Wilson K, Finkenstadt BF, Coulson TN, Murray S, Albon SD et al. (1998). Noise and determinism in synchronized sheep dynamics. Nature 394: 674-677.

Hessen DO, Faafeng BA, Smith VH, Bakkestuen V, Walsdeng B. (2006). Extrinsic and intrinsic controls of zooplankton diversity in lakes. Ecology 87: 433-443.

Hudson PJ, Cattadori IM. (1999). The Moran effect: a cause of population synchrony. Trends Eco Evol 14: 1-2.

Jackson DA. (1995). PROTEST - a Procrustean randomization test of community-environment concordance. Ecoscience 2: 297-303.

Jarvinen M, Rask M, Ruuhijarvi J, Arvola L. (2002). Temporal coherence in water temperature and chemistry under the ice of boreal lakes (Finland). Water Res 36: 3949-3956.

Kent AD, Jones SE, Newton RJ, Lauster GH, Graham J, Triplett EW et al. (2006). Experimental manipulations of microbial food web interactions in a humic lake: shifting biological drivers of bacterial community structure. Environ Microbiol 8: 1448-1459.

Kent AD, Jones SE, Yannarell AC, Lauster GH, Graham JH, Kratz TK et al. (2004). Annual patterns in bacterioplankton community variability in a humic lake. Microb Ecol 48: 550-560.

Kisand V, Tammert H. (2000). Bacterioplankton strategies for leucine and glucose uptake after a cyanobacterial bloom in an eutrophic shallow lake. Soil Biol Biochem 32: 1965-1972. 
Kratz TK, Soranno PA, Benson BJ, Baines SB, Magnuson JJ, Frost TF et al. (1998). Inter-annual synchronous dynamics in north temperate lakes in Wisconsin, USA. In: George DG, Jones JC, Punochar P, Reynolds DS, Sutcliffe DW (eds). Management of Lakes and Reservoirs during Global Climate Change. Kluwer Academic Publishers: The Netherlands, pp 273-287.

Legendre P, Legendre L. (1998). Numerical Ecology. Elsevier Science: BV, Amsterdam.

Liebhold A, Koenig WD, Bjørnstad ON. (2004). Spatial synchrony in population dynamics. Ann Rev Ecol Evol Syst 35: 467-490.

Magnuson JJ, Benson BJ, Kratz TK. (1990). Temporal Coherence in the Limnology of a Suite of Lakes in Wisconsin, USA. Freshw Biol 23: 145-159.

Magnuson JJ, Benson BJ, Lenters JD, Robertson DM. (2005). Coherent dynamics among lakes. In: Magnuson JJ, Kratz TK, Benson BJ (eds). Long Term Dynamics of Lakes in the Landscape. Oxford Press: Oxford, pp 89-106.

Malcolm RL. (1990). The uniqueness of humic substances in each of soil, stream and marine environments. Anal Chim Acta 232: 19-30.

Paszkowski CA, Tonn WM. (2000). Community concordance between the fish and aquatic birds of lakes in northern Alberta, Canada: the relative importance of environmental and biotic factors. Freshw Biol 43: 421-437.

Patterson D. (1998). Free-Living Freshwater Protozoa. John Wiley \& Sons: New York.

Peres-Neto PR, Jackson Da. (2001). How well do multivariate data sets match? The advantages of a Procrustean superimposition approach over the Mantel test. Oecologia 129: 169-178.

Pinhassi J, Sala MM, Havskum H, Peters F, Guadayol O, Malits A et al. (2004). Changes in bacterioplankton composition under different phytoplankton regimens. Appl Environ Microbiol 70: 6753-6766.

Porter K, Feig Y. (1980). The use of DAPI for identifying and counting aquatic microflora. Limnol Oceanogr 25: 943-948.

Prescott G. (1954). Algae of the Western Great Lakes. Cranbrook Institute of Science: Bloomfield Hills, Michigan.

Rees GN, Baldwin DS, Watson GO, Perryman S, Nielsen DL. (2004). Ordination and significance testing of microbial community composition derived from terminal restriction fragment length polymorphisms: application of multivariate statistics. Anton Leeuw Int J G 86: 339-347.
Rusak JA, Kratz TK. (2003). Meterological Data for the North Temperate Lakes Study Area. North Temperate Lakes Long Term Ecological Research Program, University of Wisconsin-Madison.

Rusak JA, Yan ND, Somers KM, McQueen DJ. (1999). The temporal coherence of zooplankton population abundances in neighboring north-temperate lakes. Am Nat 153: $46-58$.

Smith GM. (1950). The Freshwater Algae of the United States. McGraw-Hill: New York.

Sommer U. (ed) (1989). Plankton Ecology: Succession in Planktonic Communities. Springer-Verlag: Berlin. Brock/Springer Series in Contemporary Bioscience, 369p.

Stanley EH. (2003). Chemical Limnology of North Temperate Lakes LTER Primary Study Lakes. North Temperate Lakes Long Term Ecological Research Program, University of Wisconsin-Madison.

Stepanauskas R, Moran MA, Bergamaschi BA, Hollibaugh JT. (2003). Covariance of bacterioplankton composition and environmental variables in a temperate delta system. Aquat Microbial Ecol 31: 85-98.

Sugihara G. (1995). Ecology - from out of the blue. Nature 378: 559-560.

ter Braak CJF, Smilauer P. (2002). CANOCO Reference Manual and CanoDraw for Windows User's Guide: Software for Canonical Community Ordination (version 45). Microcomputer Power: Ithaca, NY.

van Hannen EJ, Mooij W, van Agterveld MP, Gons HJ, Laanbroek HJ. (1999). Detritus-dependent development of the microbial community in an experimental system: qualitative analysis by denaturing gradient gel electrophoresis. Appl Environ Microbiol 65: 2478-2484.

Wetzel RG, Hatcher PG, Bianchi TS. (1995). Natural photolysis by ultraviolet irradiance of recalcitrant dissolved organic matter to simple substrates for rapid bacterial metabolism. Limnol Oceanogr 40: 1369-1380.

Yannarell AC, Kent AD, Lauster GH, Kratz TK, Triplett EW. (2003). Temporal patterns in bacterial communities in three temperate lakes of different trophic status. Microb Ecol 46: 391-405.

Yannarell AC, Triplett EW. (2004). Within- and betweenlake variability in the composition of bacterioplankton communities: investigations at multiple spatial scales. Appl Environ Microbiol 70: 214-223.

Yannarell AC, Triplett EW. (2005). Geographic and environmental sources of variation in lake bacterial community composition. Appl Environ Microbiol 71: 227-239. 